\title{
Shift in detrital sedimentation in the eastern Bay of Bengal during the late Quaternary
}

\author{
C Prakash Babu ${ }^{1, *}$, J N Pattan ${ }^{1}, \mathrm{~K}_{\text {Dutta }}^{2}$, N Basavaiah ${ }^{3}$, \\ G V RAvi PrasaD ${ }^{2}$, D K RAY ${ }^{2}$ and P GoviL ${ }^{4}$ \\ ${ }^{1}$ National Institute of Oceanography (CSIR), Dona Paula 403004 , Goa, India. \\ ${ }^{2}$ AMS Radiocarbon Laboratory, Institute of Physics, Bhubaneswar 751 005, Orissa, India. \\ ${ }^{3}$ Indian Institute of Geomagnetism, Kalamboli, New Panvel, Navi Mumbai 410 218, India. \\ ${ }^{4}$ National Centre for Antarctic and Ocean Research, Headland Sada, Vasco 403 804, Goa, India. \\ *e-mail: pbabu@nio.org
}

\begin{abstract}
Down-core variations of granulometric, geochemical and mineral magnetism of a 70-cm long sediment core retrieved from the eastern Bay of Bengal abyssal region were studied to understand sedimentation pattern and sediment provenance during the last $\sim 12 \mathrm{kyr}$ BP. Based on down-core physical and elemental variations, three units were identified: unit $3(70-43 \mathrm{~cm})$ is a $\sim 30 \mathrm{~cm}$ thick clayey silt organic carbon-rich $(0.5-0.92 \%)$ turbidite probably delivered by the Brahmaputra River during the late Quaternary period. Units $2(43-24 \mathrm{~cm})$ and $1(24-0 \mathrm{~cm})$ represent enhanced and reduced supply of coarse-grained detrital sediments from the Ganges River during early and late Holocene period, respectively. Increased terrigenous supply dilutes calcium carbonate $\left(\mathrm{CaCO}_{3}\right)$ and biogenic elements $(\mathrm{P}, \mathrm{Ba}$ and $\mathrm{Cu})$ in units 3 and 2. On the contrary, a reduction in detrital input enhances $\mathrm{CaCO}_{3}$ and biogenic elements in unit 1. Lithogenic elements ( $\mathrm{Ti}, \mathrm{Al}, \mathrm{K}$ and $\mathrm{Rb}$ ) and shale-normalized REE patterns in all three units suggest terrigenous source. The shift in provenance from the Brahmaputra to the Ganges derived sediments is evident by a sharp increase in sediment grain size, increased concentration and grain size assemblages of magnetic minerals, lithogenic elements concentration and $\mathrm{La}_{\mathrm{n}} / \mathrm{Yb}_{\mathrm{n}}$ ratio. This study highlights terrigenous dilution on biogenic sedimentation in the eastern Bay of Bengal sediments.
\end{abstract}

\section{Introduction}

The Bay of Bengal receives large quantities of fresh water from the adjacent coastal mountain rivers $\left(1.6 \times 10^{12} \mathrm{~m}^{3} \mathrm{yr}^{-1}\right.$; Subramanian 1993) and over 1350 million tonnes of suspended sediment every year (Milliman and Meade 1983; Subramanian 1985). The lithogenic sediments in the Bay of Bengal derived from erosion of the Himalayan and Indo-Burman ranges holds a key in understanding monsoon variations, weathering patterns, river run-off and sediment provenance. In the Bay of Bengal, the sediments are mainly derived from:

- Ganges-Brahmaputra Rivers,
- Irrawaddy River, and

- Western part of the Indo-Burman ranges (Colin et al 1999).

Several major rivers supply lithogenic material to eastern part of the Bay of Bengal. The distal Bengal Fan receives sediment mainly by turbidites (Coleman 1969; Stow et al 1990). The redox sensitive elements re-organize and concentrate at the oxidation fronts (oxic/weakly reducing) when an organic-rich turbidite emplaces in the abyssal regions overlain by oxygenated water column. Physical and inorganic geochemical methods are adopted generally to distinguish the terrigenous signature from biogenic sedimentation and to

Keywords. Bay of Bengal; sediment core; calcium carbonate; dilution; detrital; biogenic; turbidite; Ganges-Brahmaputra. 


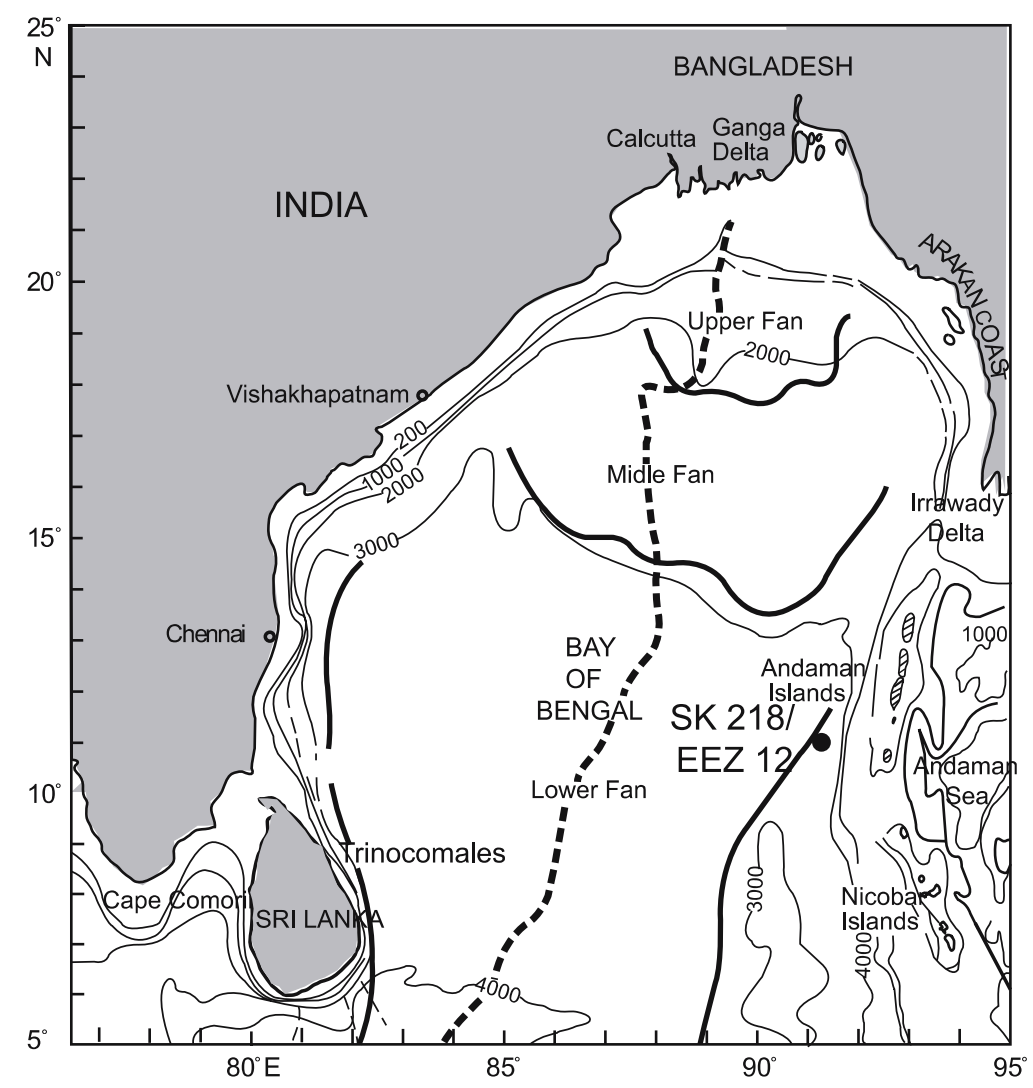

Figure 1. Map showing location of the sediment core (SK 218/EEZ-12). Bathymetric depth contours are in meters. The thick solid line demarcates the boundaries between upper, middle and lower fans. The thick dashed line represents the active turbidity current channel.

discern sediment provenance. The aim of the present study is to distinguish the terrigenous and biogenic sediments, to understand the influence of terrigenous dilution and/or productivity on the calcium carbonate $\left(\mathrm{CaCO}_{3}\right)$ and biogenic elements $(\mathrm{P}, \mathrm{Ba}$ and $\mathrm{Cu}$ ), to identify paleoxidation fronts and the provenance of terrigenous sediments with time. Due to limited ${ }^{14} \mathrm{C}$ derived ages, the down-core variations of terrigenous and biogenic elements were discussed on a broader time scale.

\section{Study area}

The Bay of Bengal is a part of the northern tropical Indian Ocean and is characterized by seasonally reversing monsoonal wind forcing and associated reversal in surface circulation. In the Bay of Bengal, the reversal in coastal circulation is due to the interplay between local and remote forcing (Shankar et al 2002 and references therein). A strong seasonal anticyclonic western boundary current forms in the Bay of Bengal during January, is best developed during March-April and decays by June (Shetye et al 1993; Babu et al 2003). During the summer monsoon, the circulation reverses and northward current prevails along the coast (Shetye et al 1991). Weak and localized coastal upwelling was observed during the summer monsoon in the western Bay of Bengal (Shetye et al 1991). Strong southwest wind during the summer brings maximum rainfall over most parts of the Indian subcontinent whereas the NE wind during winter brings heavy rains to southeastern part of India (Ramage 1971). On an average, the annual rainfall over the Bay of Bengal exceeds $\sim 2 \mathrm{~m}$ (Prasad 1997). A strong halocline (Prasanna Kumar et al 2002) in the Bay of Bengal lowers productivity compared to the Arabian Sea (Madhupratap et al 2003).

The productivity in western coastal and open ocean stations in the Bay of Bengal during summer monsoon ranges between 40 and $502 \mathrm{mg} \mathrm{C} \mathrm{m}^{-2} \mathrm{~d}^{-1}$ and 89 and $221 \mathrm{mg} \mathrm{C} \mathrm{m}^{-2} \mathrm{~d}^{-1}$, respectively (Madhupratap et al 2003). Low productivity values during summer monsoon are due to upper low saline waters which inhibits introduction of nutrients from below (Prasanna Kumar et al 2002). Eddy pumping is a possible mechanism for vertical transfer of nutrients and enhanced productivity during summer by a factor of 2 to 8 
Table 1. ${ }^{14} C(A M S)$ derived dates of SK 218/EEZ-12.

\begin{tabular}{lcccc}
\hline $\begin{array}{c}\text { Sample } \\
\text { interval } \\
(\mathrm{cm})\end{array}$ & Lab. IP & $\begin{array}{c}\text { Calendar }{ }^{14} \mathrm{C} \\
\text { age (BP) }\end{array}$ & $\begin{array}{c}\text { Calibrated }{ }^{14} \mathrm{C} \\
\text { age (BP) }\end{array}$ & $\begin{array}{c}\text { One sigma range } \\
\text { (BP) }\end{array}$ \\
\hline $0-1$ & IP-472 & $2433 \pm 146$ & $2073 \pm 179$ & $1894-2251$ \\
$22-23$ & IP-474 & $5757 \pm 102$ & $6148 \pm 116$ & $6032-6263$ \\
$60-61$ & IP-476 & $10,110 \pm 123$ & $11,058 \pm 162$ & $10,896-11,220$ \\
\hline
\end{tabular}

compared to non-eddy regions in the Bay of Bengal (Prasanna Kumar et al 2004).

\section{Material and methods}

A $70 \mathrm{~cm}$ long sediment gravity core was recovered (lat. $11^{\circ} 00.44^{\prime} \mathrm{N}$ and long. $91^{\circ} 20.10^{\prime} \mathrm{E}$, water depth $3417 \mathrm{~m}$ ) during ORV Sagar Kanya cruise 218 (SK 218/EEZ 12; figure 1) from the eastern Bay of Bengal. After sub-sampling at $1 \mathrm{~cm}$ interval, the samples were oven dried at $60^{\circ} \mathrm{C}$, powdered and homogenized by using agate ball mill. Inorganic carbon (IC) measurements were carried out after acidification of the sample with $1 \mathrm{~N} \mathrm{HCl}$ and measured the $\mathrm{CO}_{2}$ by UIC CM 5014 coulometer. Total carbon (TC) and nitrogen were measured with a CE NCS 2500 elemental analyzer. The analytical accuracy and precision for total and inorganic carbon were better than $\pm 5 \%$. Total organic carbon (TOC) was calculated as the difference between TC and IC. Sediment grain size measurements were carried out using the Malvern laser particle size analyzer (Master-Sizer 2000) after removing carbonate and organic carbon.

The ${ }^{14} \mathrm{C}$ measurements were done by accelerator mass spectrometry (AMS), using the NEC 3MV 9SDH-2 pelletron accelerator at the Institute of Physics, Bhubaneswar (Ravi Prasad et al 2008). For ${ }^{14} \mathrm{C}$ analyses, about $20 \mathrm{mg}$ of adult $(250-450 \mu)$ surface dwelling foraminifer species were separated from the sediments, etched for $10 \mathrm{~s}$ in an aqueous solution of $0.1 \% \mathrm{HCl}$ and $10 \% \mathrm{H}_{2} \mathrm{O}_{2}$ solution, and hydrolysed in vacuum with concentrated $\mathrm{H}_{3} \mathrm{PO}_{4}$. The liberated $\mathrm{CO}_{2}$ was purified in a vacuum line, and converted into graphite by reducing with ultrapure hydrogen $\left(\mathrm{H}_{2}\right)$ gas in the presence of an iron $(\mathrm{Fe})$ catalyst (Vogel et al 1984). All ${ }^{14} \mathrm{C}$-ages were normalized with uniform $\delta^{13} \mathrm{C}$ of $+1.5 \%$. The ${ }^{14} \mathrm{C}$-ages of these marine samples were calibrated with Calib 5.1 calibration program using Marine04 dataset (Hughen et al 2004). For calibration, $\Delta-\mathrm{R}$ correction value of $16 \pm 8$ years was assumed for the core location in the eastern Bay of Bengal near Andaman and Nicobar Islands (Dutta et al 2001; Southon et al 2002). The AMS derived ${ }^{14} \mathrm{C}$ dates are provided in table 1 . The calibrated ages are used for discussion.

\subsection{Major and trace element analyses}

The powdered sediment samples were digested in teflon beakers with a mixture of $\mathrm{HF}, \mathrm{HClO}_{4}$ and $\mathrm{HNO}_{3}$. Major and minor elements were analyzed by Inductively Coupled Plasma-Optical Emission Spectrometer (ICP-OES). The analytical precision with respect to the international reference materials (MAG-1 and SCo-1) for major and minor elements was better than 5 and $10 \%$, respectively. Rare earth elements (REE) and few trace element analysis were carried out using a Perkin Elmer Elan DRC II Inductively Coupled Plasma-Mass Specrtometer (ICP-MS) following the procedure of Balaram and Rao (2003). The analytical accuracy of REE and trace elements was $\pm 1 \%$ and $\pm 5 \%$, respectively compared to MAG-1.

\subsection{Environmental magnetic mineral measurements}

In order to characterize the mineralogy and grain size of the magnetic phases present in the sediment core, a range of mass specific mineral (rock) magnetic measurements were carried out following the procedure of Basavaiah and Khadkikar (2004). The measurements include low-frequency $(0.47 \mathrm{kHz})$ and high-frequency $(4.7 \mathrm{kHz})$ magnetic susceptibility $(\chi)$, anhysteretic remanent magnetization (ARM) acquired in a d.c. field of $0.05 \mathrm{mT}$ with a peak a.c. field of $100 \mathrm{mT}$ and isothermal remanent magnetization (IRM) imparted in a $1 \mathrm{~T}$ (= SIRM). Immediately after growth and measurement of SIRM, the sample was placed in a series of increasing back-fields of $20,30,40,60,100$ and $300 \mathrm{mT}$ and its IRM was measured. These were measured using a Bartington dual frequency sensor, Molspin AF demagnetizer, Molspin pulse magnetizer and a Molspin spinner magnetometer at the Environmental Magnetism Laboratory, (Navi) Mumbai. Various quotients of rock magnetic parameters were calculated in an attempt to estimate grain size and mineralogy of magnetic components. $\chi_{\mathrm{FD}} \%$ calculated using $\chi_{\mathrm{LF}}$ and $\chi_{\mathrm{HF}}$ with the formula $\chi_{\mathrm{FD}} \%=\left(\chi_{\mathrm{LF}}-\chi_{\mathrm{HF}}\right) / \chi_{\mathrm{LF}} * 100$ (Mullins and Tite 1973), represents the concentration of the superparamagnetic (SP) mineral fraction in a sample. 


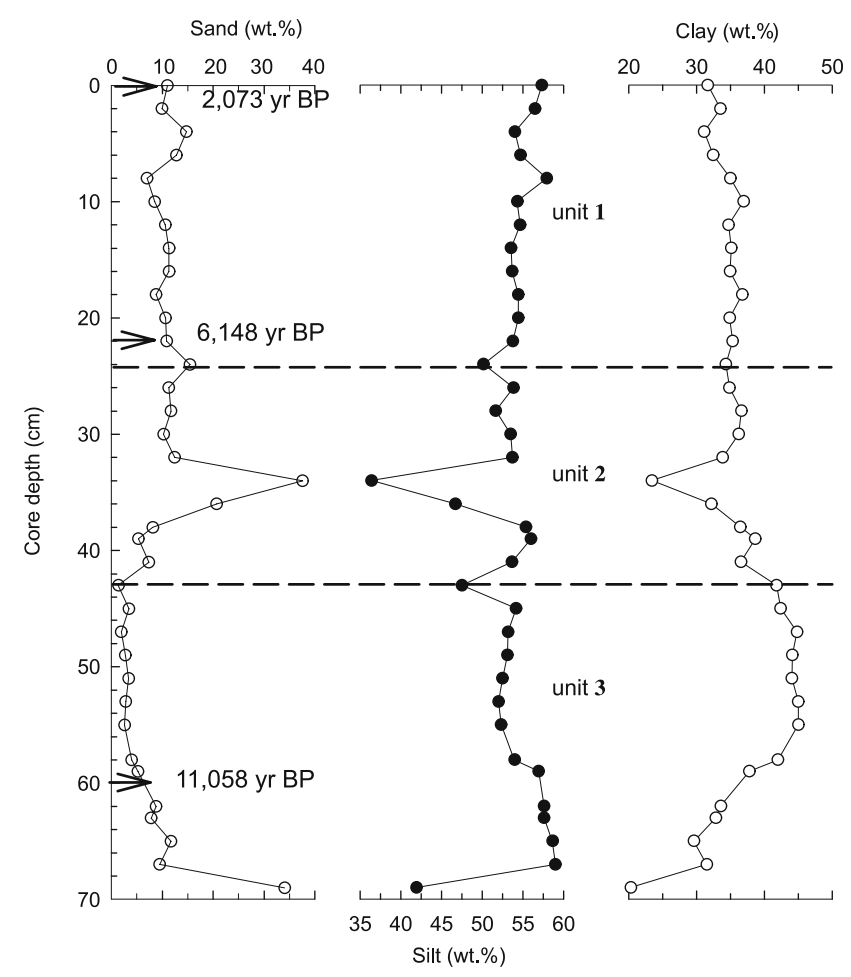

Figure 2. Down-core variations of sand, silt and clay. Note the presence of a sharp enrichment of sand at core bottom and in the middle of unit 2 . AMS ${ }^{14} \mathrm{C}$ (calibrated) derived ages are shown with an arrow mark.

The S-ratio is simplified as S-ratio $=$ IRM at reverse 100 and $300 \mathrm{mT} / \mathrm{SIRM}$. S-ratio $\left(\mathrm{IRM}_{-0.3 \mathrm{~T}} /\right.$ SIRM) values close to zero indicate pure hematite; values close to one indicate pure magnetite (Bloemendal et al 1992).

\section{Results}

Based on down-core profiles of sediment grain size, magnetic studies and elemental variations, the core was broadly divided into three units: unit 3 $(70-43 \mathrm{~cm})$ represents a clayey-silt organic rich turbidite, unit $2(43-24 \mathrm{~cm})$ consists of coarse-grained terrigenous sediments whereas biogenic sediments dominate unit $1(24-0 \mathrm{~cm})$. Based on age $\left({ }^{14} \mathrm{C}\right.$ AMS) vs. depth it was observed that units 3 and 2 have higher sedimentation rates $(7.8 \mathrm{~cm} / \mathrm{ka})$ than unit $1(5.5 \mathrm{~cm} / \mathrm{ka})$. The average sedimentation rate for unit 3 was calculated for $60-43 \mathrm{~cm}$ interval as ${ }^{14} \mathrm{C}$ AMS dates were not carried out after $60 \mathrm{~cm}$.

A high sand content $(34 \%)$ at the core bottom (unit 3) was followed by an increase in silt (42-59\%) and clay (38-42\%; figure 2). Highest percentage of sand $(38 \%)$ was observed in the middle of unit 2. The percentage of sand shows a marginal decrease in unit 1 and a minor increase towards core top (figure 2). The lithogenic elements ( $\mathrm{Fe}, \mathrm{Ti}, \mathrm{Al}, \mathrm{K}$ and $\mathrm{Rb}$ ) show highest concentrations in unit 3, decrease in unit 2 and a marginal decrease but near uniform concentrations in unit 1 (figure 3). On the other hand, the $\mathrm{CaCO}_{3}$ and biogenic elements concentration were low in unit 3 , an increasing trend in unit 2 and reach maximum but near uniform values in unit 1 (figure 4). TOC temporal variation closely follows the sediment texture being low in the sand and silt layer $(0.17-0.50 \%)$ and high in the clay layer (0.27-0.92\%; figure 4) of unit 3 . The sandy sediments in unit 2 contain the lowest TOC concentrations $(0.32-0.36 \%)$. The redox sensitive elements (Fe, $\mathrm{V}$ and $\mathrm{U}$ ) show sharp, narrow and broad peaks between 51 and $55 \mathrm{~cm}$ in unit 3 (figure 5).

Detrital magnetic mineral concentration parameters $\chi_{\mathrm{LF}}, \chi_{\mathrm{ARM}}$, SIRM, Soft IRM and HIRM generally display:

- relatively low values in unit 3 reaching lowest values between 53 and $55 \mathrm{~cm}$;

- a gradual increase from the base of unit 2 followed by sharp increase towards top of this unit; and

- near constant values in unit 1 (figure 6).

The concentration independent $\chi_{\mathrm{FD}} \%$ show low values at the bottom of unit 3 but shows a sharp decrease at $55 \mathrm{~cm}$ coinciding with $\chi_{\mathrm{LF}}$. This decrease was accompanied by slight increase in the remaining part of unit 3 along with $\chi_{\mathrm{ARM}} / \chi_{\mathrm{LF}}$ and $\chi_{\mathrm{ARM}} / \mathrm{SIRM}$. The magnetic grain size parameters such as $\chi_{\mathrm{ARM}} / \chi_{\mathrm{LF}}$ and $\chi_{\mathrm{ARM}} / \mathrm{SIRM}$ show a significant decrease in unit 2 but near constant in unit 1. In contrast to uniform Soft IRM and HIRM in units 3 and 1 , unit 2 shows a gradual increase from the base to a sharp rise to the top of the unit. S-ratio shows a sharp decrease at $55 \mathrm{~cm}$.

Total REE ( $\mathrm{REEE}$ ) concentration ranges between 140 and $192 \mathrm{ppm}$ with an average of $156 \pm 12 \mathrm{ppm}$ (figure 7a). Average $\Sigma$ REE content was relatively higher in unit 3 (166 ppm) compared to units 2 and 1 (153 and $148 \mathrm{ppm}$; figure $7 \mathrm{~b}$ ). The $\mathrm{La}_{\mathrm{n}} / \mathrm{Yb}_{\mathrm{n}}$ ratio was relatively high in unit 3 $(1.0-1.3)$ but low and uniform $(\sim 1)$ in units 2 and 1. Shale-normalized REE patterns in all the units show a small but a distinct positive Eu-anomaly (figure 7c).

\section{Discussion}

The sediment colour variation from gray $(70-43 \mathrm{~cm})$ to brownish $(40-0 \mathrm{~cm})$ suggest change in sedimentation pattern and their provenance. The sediment grain size as well as magnetic grain size, magnetic mineralogy and elemental variations are used to distinguish the terrigenous from biogenic sediments and in identifying the sediment provenance. An inverse trend between terrigenous and biogenic sediments highlights terrigenous 


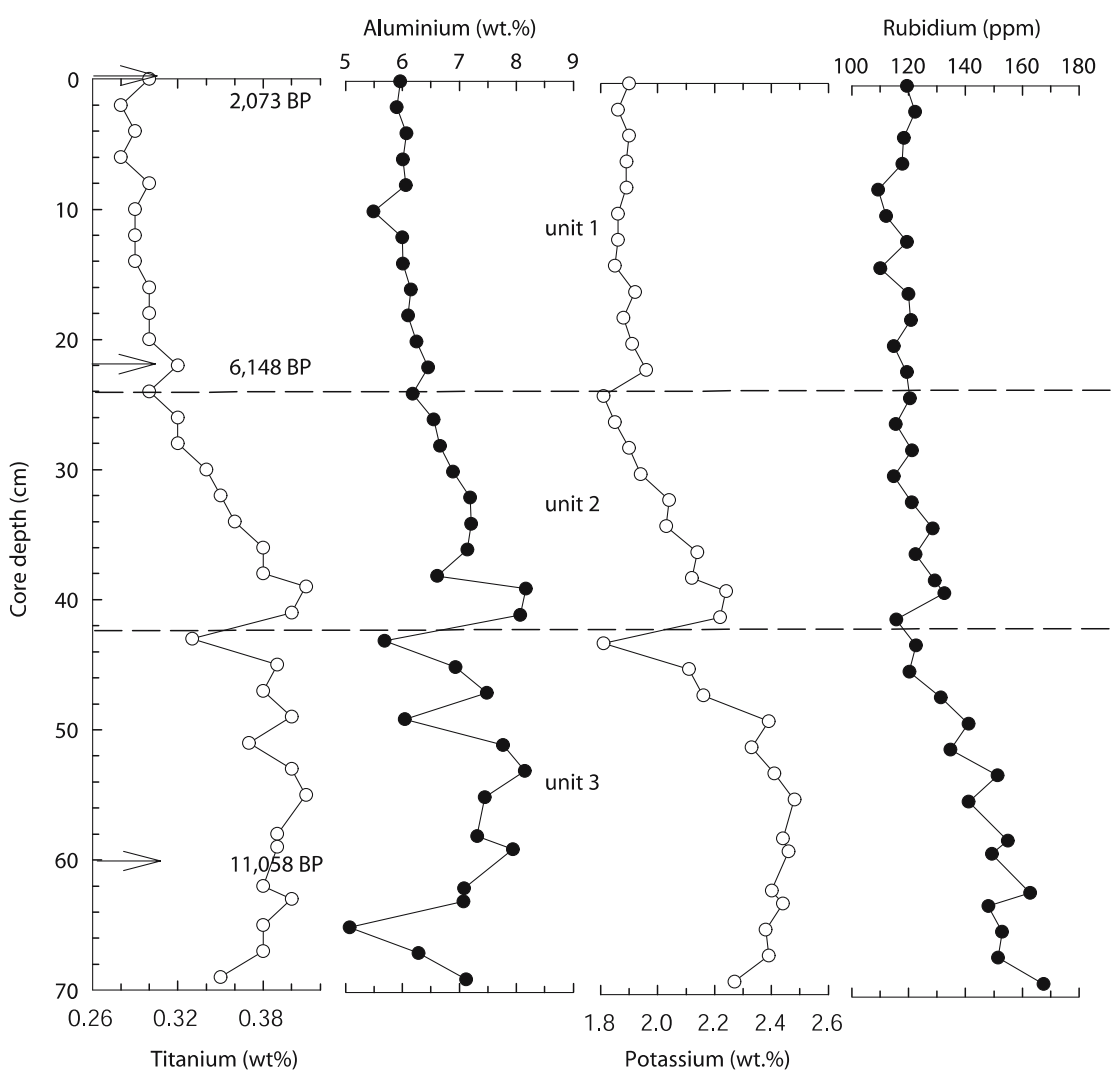

Figure 3. Down-core variations of lithogenic elements $\mathrm{Ti}, \mathrm{Al}, \mathrm{K}$ and $\mathrm{Rb}$. Note maximum concentration of lithogenic elements in unit 3 , a decreasing trend in unit 2.

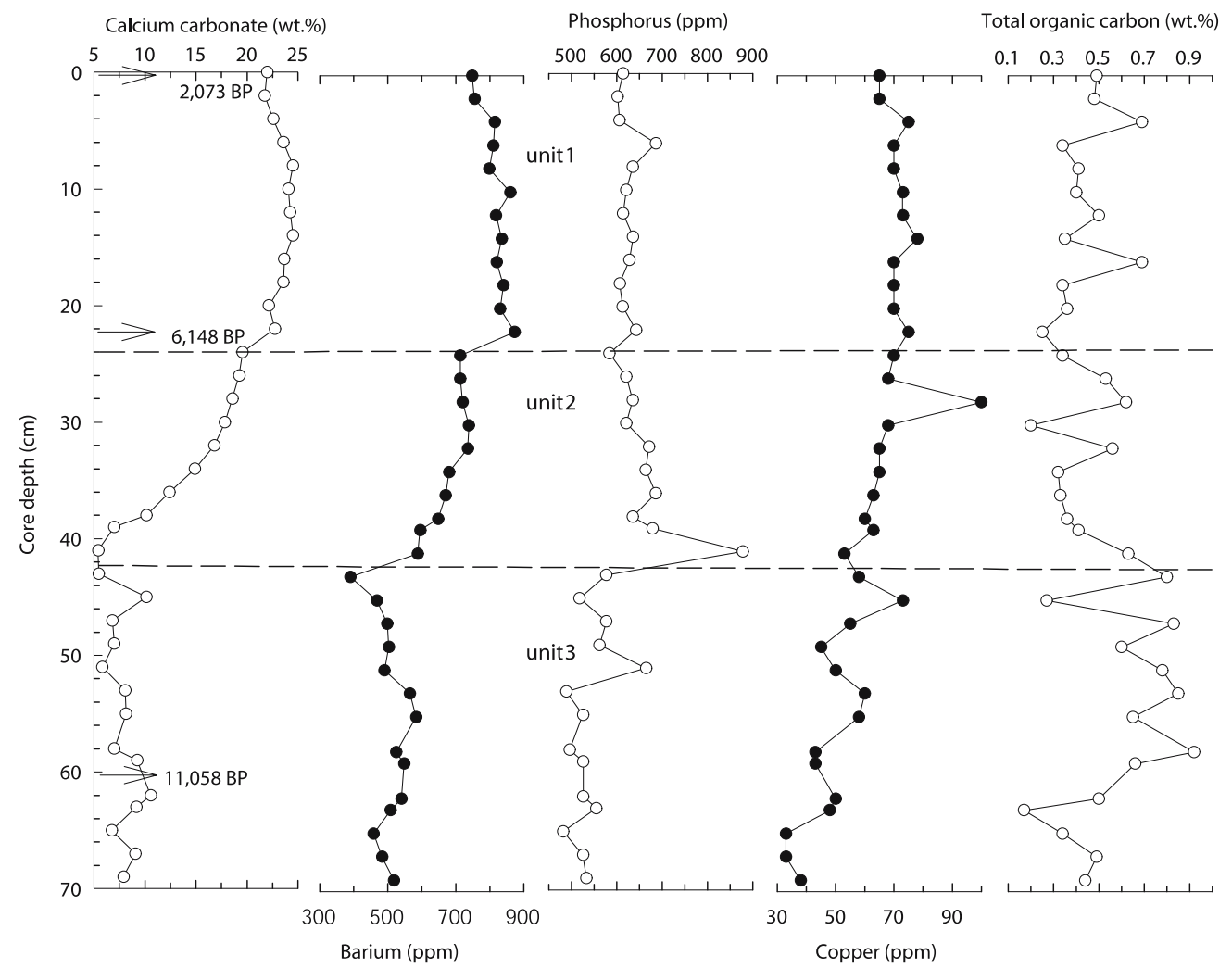

Figure 4. Down-core variations of biogenic elements $\mathrm{CaCO}_{3}, \mathrm{Ba}, \mathrm{P}, \mathrm{Cu}$ and total organic carbon (TOC). Note the accumulation of biogenic elements in unit 1 . 


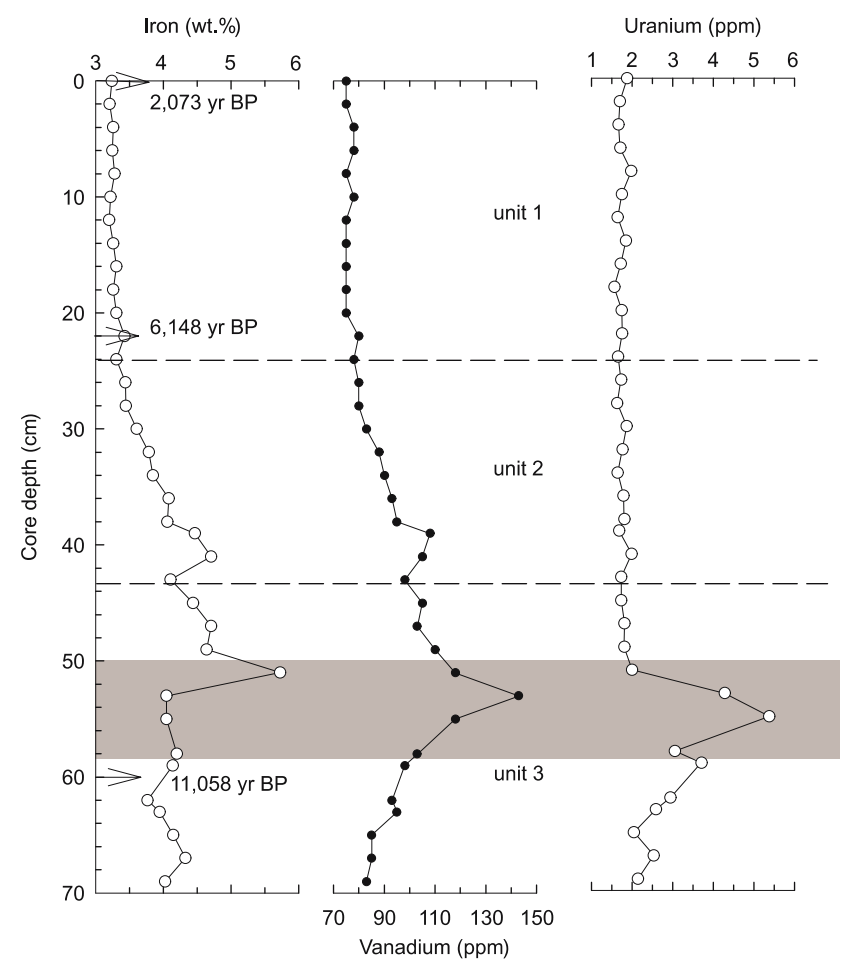

Figure 5. Redox sensitive elements (Fe, V and U) downcore variations. The redox sensitive elements concentrate at the paleoredox front which is shown as a gray bar in unit 3 .

dilution on biogenic element variations. Although the sediment texture as well as magnetic grain size in unit 2 confirms the presence of coarse size sediments, the lithogenic elements surprisingly show a decreasing trend.

\subsection{Turbidite sedimentation and paleoxidation fronts in unit 3}

Gradual decrease in grain size towards top of unit 3 (figure 2) indicate the possibility of a turbidite. The thickness of this turbidite corresponds with light gray silt and silt-mud turbidites (Facies 1) of Stow et al (1990). High concentration of lithogenic elements corroborates the enhanced supply of terrigenous material diluting $\mathrm{CaCO}_{3}$ and biogenic elements. Dissolution of carbonate is ruled out as the core is retrieved from relatively shallower depths relative to the deeper carbonate compensation depth (CCD) at these latitudes (5000 m, Kolla and Kidd 1982). The lithogenic elements concentration in this unit broadly corresponds with the Brahmaputra River sediments (table 2; Datta and Subramanian 1998). High Fe, K and Rb are due to the presence of chlorite and feldspars in the Brahmaputra bed load and suspended sediments (Subramanian 1979; Subramanian et al 1987). Both $\mathrm{Fe}$ and $\mathrm{Al}$ show correspondence with fine grain size suggesting enhanced adsorption due to greater surface area of fine size material (figures 2 and 5).

Low TOC $(<0.50 \%)$ in the sand and silt layer is due to oxidation of organic matter whereas the absorption of TOC to clay enriches TOC in fine size sediments. The relation between TOC and grain size is in concert with Galy and France-Lanord (2001) who have also noted a similar co-variation of TOC with size and mineralogy in the Bay of Bengal sediments.

$\chi_{\mathrm{LF}}$, ARM, SIRM, low-field remanence (Soft $\left.\mathrm{IRM}=\mathrm{SIRM}-\mathrm{IRM}_{-30 \mathrm{mT}}\right)$ and high-field remanence $\left(\mathrm{HIRM}=\mathrm{SIRM}-\mathrm{IRM}_{-300 \mathrm{mT}}\right)$ measure the concentration of magnetic materials. Soft IRM provides information on the concentration of lowcoercivity ferromagnetic minerals dominating the magnetic mineralogy such as magnetites and titanomagnetites and HIRM indicates the relative concentration of high-coercivity antiferromagnetic minerals such as hematite and goethite. Anhysteretic susceptibility $\left(\chi_{\mathrm{ARM}}\right)$ and the normalized ratios $\chi_{\mathrm{ARM}} / \chi_{\mathrm{LF}}$ and $\chi_{\mathrm{ARM}} / \mathrm{SIRM}$ could be interpreted as reflecting changes in the grain size of the ferrimagnetic fraction (King et al 1982). Higher values represent finer-grained magnetic minerals. The low magnetic mineral concentration between 53 and $55 \mathrm{~cm}$ is reflected in the decreasing trend of $\chi_{\mathrm{LF}}$ and $\chi_{\mathrm{ARM}}$ which may probably demonstrate dissolution of magnetic minerals due to reductive diagenesis (figure 6). The decreasing trend of $\chi_{\mathrm{FD}} \%$ and $\chi_{\mathrm{ARM}}$ further denotes low concentration of ultrafine SP and single domain (SD) minerals and reinforces magnetic mineral dissolution. The sharp decline in S-ratio corroborates dissolution of ferrimagnetic minerals, more susceptible for reductive diagenesis, during organic matter oxidation. The presence of fine size ferrimagnetic minerals as revealed from $\chi_{\mathrm{FD}} \%, \chi_{\mathrm{ARM}} / \mathrm{SIRM}, \chi_{\mathrm{ARM}} / \chi_{\mathrm{LF}}$ substantiates dissolution of magnetic minerals. Sahota et al (1995) have also reported low concentration of magnetic minerals and a sharp decrease in S-ratios due to reductive diagenesis at the paleoxidation fronts in the Maderia Abyssal Plain sediments. Relatively low values of Soft IRM and HIRM in this unit may also be related with the dissolution of soft and hard coercivity components (figure 6).

The sharp and broad peaks of $\mathrm{V}$ and $\mathrm{U}$ between 53 and $55 \mathrm{~cm}$ (figure 5) occur at a depth that is not associated with any textural change. These peaks are formed due to elemental mobilization during downward movement of oxidation front when an organic-rich turbidite layer emplaces in oxygenated water column. The sharp $\mathrm{V}$ peak is contained in $\mathrm{a}<4 \mathrm{~cm}$ interval against a high detrital $\mathrm{V}$ background (130 ppm; Wedepohl 1991). V concentration in the sea water is relatively high $(1.8-2.3 \mathrm{ppb}$; 


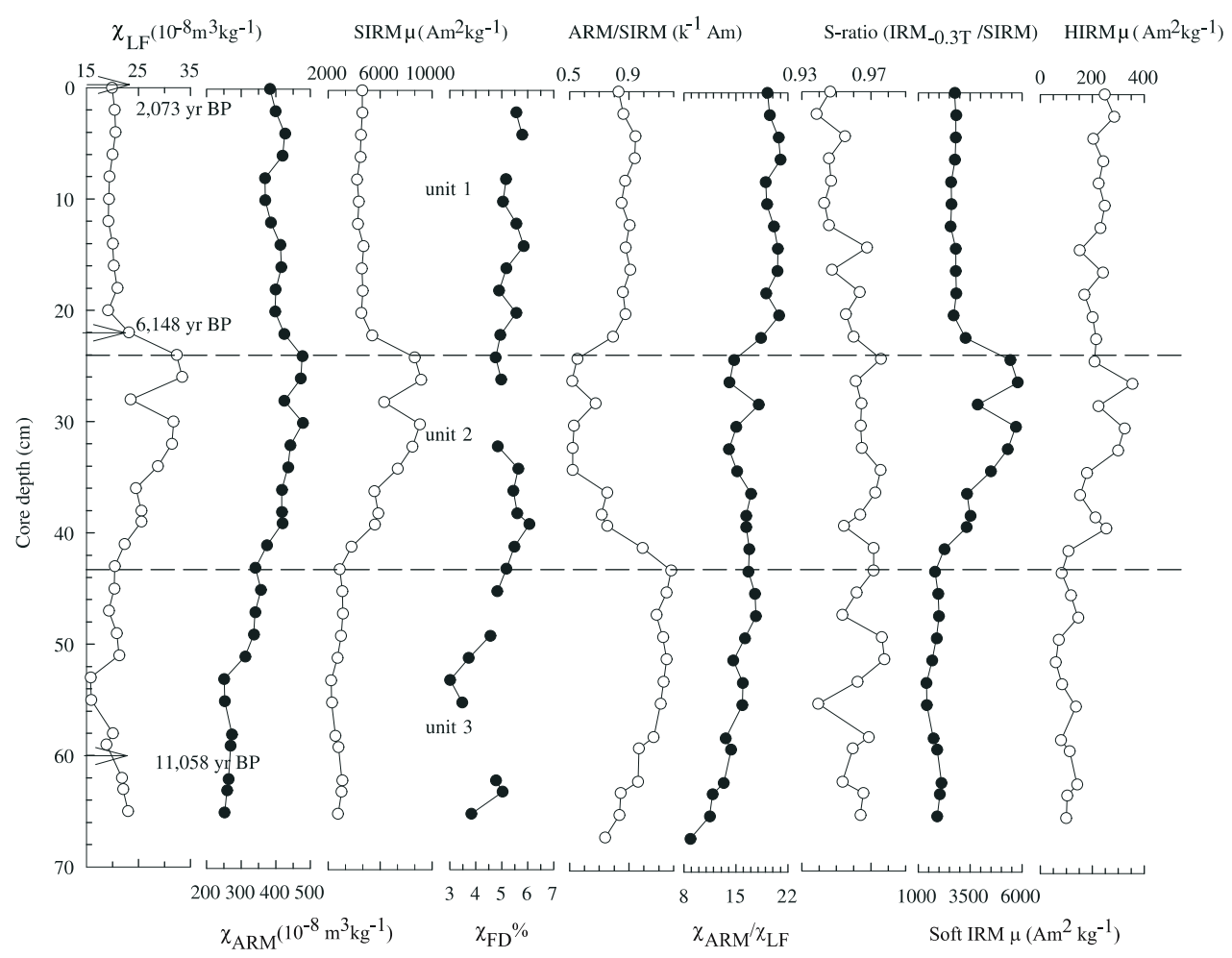

Figure 6. Down-core variation of magnetic susceptibility parameters $\left(\chi_{\mathrm{LF}}\right.$ and $\left.\chi_{\mathrm{FD}}\right), \chi_{\mathrm{ARM}}$, Soft IRM, HIRM and ratios of various rock magnetic parameters including $\chi_{\mathrm{ARM}} / \chi_{\mathrm{LF}}, \chi_{\mathrm{ARM}} / \mathrm{SIRM}$ and S-ratio.
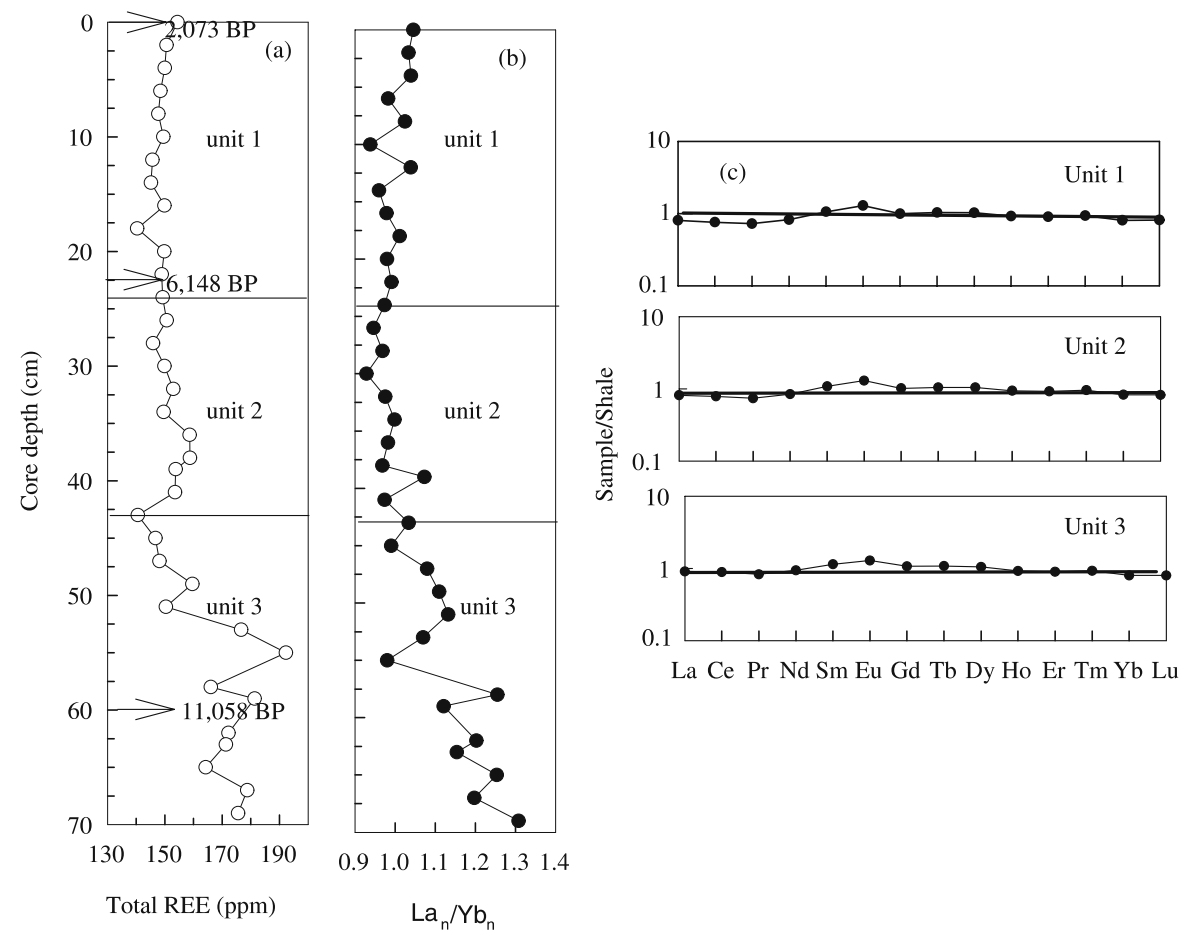

La Ce Pr Nd Sm Eu Gd Tb Dy Ho Er Tm Yb Lu

Figure 7. Down-core REE variations: (a) total REE, (b) $\mathrm{La}_{n} / \mathrm{Yb}_{\mathrm{n}}$, and (c) shale normalized average REE patterns in three units. Observe a change in the $\mathrm{La}_{\mathrm{n}} / \mathrm{Yb}_{\mathrm{n}}$ ratios between unit 3 and in units 2 and 1 suggesting a change in the provenance.

Collier 1984; Jeandel et al 1987). It appears that $\mathrm{V}$ diffusion from the water column and uptake to the solid phase under reducing conditions is a cause for augmentation of $\mathrm{V}$ below the oxidation front. The broad U peak unlike $\mathrm{V}$ can be traceable even at a coarser sampling interval (figure 5). 
Table 2. Average major (wt.\%) and minor elements concentration (ppm) in the study area along with the Ganges and Brahmaputra River sediments and tributaries.

\begin{tabular}{|c|c|c|c|c|c|c|c|c|}
\hline \multirow[b]{2}{*}{ Element } & \multicolumn{3}{|c|}{ This study } & \multirow[b]{2}{*}{$\mathrm{LG}^{a}$} & \multirow[b]{2}{*}{$\mathrm{U} \& \mathrm{MG}^{b}$} & \multirow[b]{2}{*}{$\mathrm{LB}^{a}$} & \multirow[b]{2}{*}{$\mathrm{MB}^{b}$} & \multirow[b]{2}{*}{$\mathrm{MEG}^{a}$} \\
\hline & Unit 3 & Unit 2 & Unit 1 & & & & & \\
\hline $\mathrm{Fe}$ & 4.33 & 3.78 & 3.27 & 3.80 & 2.16 & 4.22 & 2.90 & 4.65 \\
\hline $\mathrm{Ti}$ & 0.38 & 0.35 & 0.30 & 0.37 & 0.30 & 0.42 & 0.31 & 0.52 \\
\hline K & 2.31 & 2.01 & 1.89 & n.a. & n.a. & n.a. & n.a. & n.a. \\
\hline Zn & 106 & 106 & 85 & 71 & 46 & 83 & 47 & 110 \\
\hline $\mathrm{V}$ & 103 & 88 & 76 & 42 & 86 & 55 & 137 & 63 \\
\hline $\mathrm{Ni}$ & 84 & 75 & 61 & 27 & 20 & 33 & 47 & 35 \\
\hline $\mathrm{Cu}$ & 49 & 69 & 71 & 23 & 21 & 28 & 17 & 32 \\
\hline
\end{tabular}

n.a.: not available; LG: lower Ganges; U\&MG: upper and middle Ganges; LB: lower Brahmaputra; MB: middle Brahmaputra; MEG: Meghna.

${ }^{a}$ Datta and Subramanian (1988); ${ }^{b}$ Subramanian et al (1985).

Uranium is conservative in sea water due to the formation of stable and soluble U (VI) uranyl carbonate (Langmuir 1978). Under suboxic conditions, dissolved $\mathrm{U}$ is drawn into the sediments along a concentration gradient reduce to lower valency and precipitates to an insoluble phase U (IV) at about the depth of Fe remobilization or below (Barnes and Cochran 1991; Klinkhammer and Palmer 1991; Crusius et al 1996).

\subsection{Increased terrigenous sedimentation in unit 2}

The high percentage of sand infers the presence of re-suspended shelf material and the possibility of a turbidite. But the decreasing trend of lithogenic elements was surprising. The immobile elements such as $\mathrm{Al}, \mathrm{Fe}$, Ti, Th, Sc, Co, $\mathrm{Zr}$ and the REEs are usually concentrated in fine grained sediments as their host minerals occur in that size range. Dilution by coarse size sediments was responsible for the decreasing trend of size controlled lithogenic elements. The lithogenic elements concentrations nearly match with the average elemental content of the lower, middle and upper Ganges River sediments (Datta and Subramanian 1998; table 2) suggesting a shift in the provenance from the Brahmaputra in unit 3 to the Ganges River in units 2 and 1.

Mineral magnetic properties provide additional supporting evidence for the presence of coarse detrital sediments. Increasing trends of $\chi_{\mathrm{LF}}$, $\chi_{\text {ARM }}$, SIRM, Soft IRM and HIRM accompanied by decreased values of $\chi_{\mathrm{ARM}} / \mathrm{SIRM}$ and $\chi_{\mathrm{ARM}} / \chi_{\mathrm{LF}}$ corroborate increase in titanomagnetite and hematite proportion and their coarser grain size. Potential sources for titanomagnetite, the major magnetic component, could be either the Deccan basalts from western Bay of Bengal or the Sylhet basalt in the catchment area of Ganges River system. The contribution of titano magnetite from peninsular India appears unlikely as it cannot be transported as bed load across the Bay for hundreds of kilometers having physiographic modulation of about $100 \mathrm{~m}$. Moreover, anticyclonic poleward current during the summer monsoon and cyclonic currents during rest of the year advect the peninsular riverine material towards northward and southward (Shetye et al 1991, 1993; Varkey et al 1996) and do not favour cross shelf transport. The Himalayan source for the titanomagnetite was in concert with Colin et al (1998). An increase in Soft IRM and HIRM by a factor of two in unit 2 compared to units 3 and 1 suggests the presence of low and high coercivity minerals such as titanomagnetite and hematite, respectively. The hematite might be produced by the low temperature oxidation of titanomagnetite under dry conditions.

The productivity in the northern Indian Ocean was high during early Holocene due to intensification of summer monsoon (Schulz et al 1998; Neff et al 2001; Fleitmann et al 2003; Rashid et al 2007). Goodbred and Kuehl (2000) have estimated a two-fold increase in the Ganges and Brahmputra River derived terrigenous load to the Bay of Bengal due to stronger monsoon than present. The monsoon induced high sediment flux due to mass wasting might have supplied coarse size sediments diluting $\mathrm{CaCO}_{3}$ and biogenic elements. Despite terrigenous dilution, the biogenic elements maintain an increasing trend portraying enhanced productivity. Organic carbon does not show any correspondence with $\mathrm{CaCO}_{3}$ and biogenic elements variation (figure 4 ). The coarse grain size material probably limits TOC sorption to grain surfaces as suggested by Hedges and Keil (1995).

\subsection{Increased biogenic sedimentation in unit 1}

A relative reduction in sedimentation rate and terrigenous supply is supported by a decrease in 
sand content, $\chi_{\mathrm{LF}}, \chi_{\mathrm{ARM}}$ and SIRM due to less intense monsoon. Decrease in terrigenous sedimentation is responsible for high $\mathrm{CaCO}_{3}$ and biogenic elements content. As a matter of fact the productivity was low during late Holocene due to weaker monsoon compared to early Holocene (Schulz et al 1998; Neff et al 2001; Fleitmann et al 2003; Rashid et al 2007). Further the terrigenous delivery controlling the biogenic elemental down-core variations is corroborated when near core top section $(0-10 \mathrm{~cm})$ is examined. A minor increase in sand content and magnetic grain size is accompanied by a marginal decrease in biogenic elements concentration inferring dilution.

\subsection{Rare-earth elements}

Slightly lower $\Sigma$ REE content $156 \pm 12 \mathrm{ppm}$ (figure 7a) compared to average shale (173 ppm; Taylor and McLennan 1985) suggests REE dilution by varying carbonate fraction. The high $\Sigma$ REE content and $\mathrm{La}_{\mathrm{n}} / \mathrm{Yb}_{\mathrm{n}}$ ratio in unit $3(\sim 1-1.3)$ suggests an additional supply of REE. The high $\mathrm{La}_{\mathrm{n}} / \mathrm{Yb}_{\mathrm{n}}$ ratio in unit 3 and decrease of this ratio in units 2 and $1(\sim 1)$ suggest change in the source of lithogenic material (figure $7 \mathrm{~b}$ ). The high $\mathrm{La}_{\mathrm{n}} / \mathrm{Yb}_{\mathrm{n}}$ ratio in unit 3 and low in 2 and 1 units matches with the ratios of the Brahmaputra and its tributaries and the Ganges River derived sediments, respectively (Ramesh et al 2000). The flat shale-normalized REE pattern of sediments in all the three units reflects their terrigenous origin (Piper 1974). Further shale-normalized REE patterns in all the units shows a small but distinct Eu-anomaly (figure $7 \mathrm{c}$ ). The Europium anomaly could be due to the presence of hydrothermal, aeolian and sodium feldspar (Elderfield 1988; Murray et al 1991; Pattan and Higgs 1995). Since the core is located west of the Andaman Islands close to the trench, any hydrothermal input is remote. It is suspected that the presence of Eu-anomaly could be due to the presence of sodium feldspar derived from submarine weathering.

\section{Conclusions}

A sediment core retrieved from the eastern Bay of Bengal abyssal region was studied to understand the influence of terrigenous sedimentation on biogenic sediments and provenance of lithogenic sediments. The Brahmaputra River derived organic-rich silt and silt-mud turbidite dilutes carbonate and biogenic elements at bottom section of the core (unit 3) during the late Quaternary period. The occurrence of paleoxidation fronts based on the enrichment of redox sensitive elements $(\mathrm{Fe}, \mathrm{V}$ and $\mathrm{U}$ ) was identified probably for the first time in the Bay of Bengal. Dilution from the Ganges River derived coarser size sediment dilute the carbonate and biogenic elements concentration during early Holocene (unit 2) despite high productivity. However, enhanced productivity trend was maintained. A relative reduction in the Ganges River sediments due to less intense monsoon has enhanced carbonate content and biogenic elemental concentrations in spite of low productivity during late Holocene (unit 1). This study highlights the need to consider terrigenous dilution before explaining biogenic sedimentation in terms of productivity variations in the Bay of Bengal sediments.

\section{Acknowledgements}

Authors thank the Director, NIO, Goa for the permission to publish this paper. The present investigation is a part of the project "Seabed surveys of the Exclusive Economic Zone of India" by using multibeam sonar supported by the Ministry of Earth Sciences, New Delhi. The authors thank the anonymous reviewer for his constructive comments and suggestions and the editor for editorial corrections. Discussions with Drs V Ramaswamy, B Nagender Nath, V V Gopalakrishna and Ms K Nisha were acknowledged. Thanks are due to Dr G Parthiban for ICP-OES analysis, Dr Rajeev Saraswat and Mr T C Vineesh for their help at various stages during this work, Ms M Kulkarni and A Tomar for laboratory analysis and Mr R Uchil for drafting the figures. This is NIO contribution no. 4708.

\section{References}

Babu M T, Sarma Y V B, Murty V S N and Vethamony P 2003 On the circulation in the Bay of Bengal during northern spring inter-monsoon (March-April 1987); Deep-Sea Res. II $50855-865$.

Balaram V and Rao T G 2003 Rapid determination of REE's and other trace elements in geological samples by microwave acid digestion and ICP-MS; Atomic Spectroscopy 24 206-212.

Barnes C E and Cochran J K 1991 Geochemistry of uranium in Black Sea sediments; Deep-Sea Res. 38 S1237-S1254.

Basavaiah N and Khadkikar A S 2004 Environmental magnetism and its application towards paleomonsoon reconstruction; J. Indian Geophys. Union 8 1-14.

Bloemendal J, King J W, Hall F R and Doh S J 1992 Rock magnetism of Late Neogene and Pleistocene deepsea sediments: Relationship to sediment source, diagenetic processes and sediment lithology; J. Geophys. Res. 97 4361-4375.

Coleman J M 1969 Brahmaputra River channel process and sedimentation; Sedim. Geol. 3 129-239.

Colin C, Kissel C, Blamart D and Turpin L 1998 Magnetic properties of sediments in the Bay of Bengal and the Andaman Sea: Impact of rapid North Atlantic Ocean climatic events on the strength of the Indian monsoon; Earth Planet. Sci. Lett. 160 632-635. 
Colin C, Turpin L, Bertauz J, Despraries A and Kissel C 1999 Erosional history of the Himalayas and Burman ranges during the last two glacial-interglacial cycles; Earth Planet. Sci. Lett. 171 647-660.

Collier R W 1984 Particulate and dissolved vanadium in the North Pacific Ocean; Nature 309 441-444.

Crusius J, Calvert S, Pedersen T and Sage D 1996 Rhenium and molybdenum enrichments in sediments as indicators of oxic suboxic and sulfidic conditions of deposition; Earth Planet. Sci. Lett. 145 65-78.

Datta D K and Subramanian V 1998 Distribution and fractionation of heavy metals in the surface sediments of the Ganges-Brahmaputra-Meghna river system in the Bengal basin; Environ. Geol. 36 93-101.

Dutta K, Bhushan R and Somayajulu B L K $2001 \Delta$-R correction values for the Northern Indian Ocean; Radiocarbon 43 483-488.

Elderfield H 1988 The oceanic chemistry of rare earth elements; Philos. Trans. R. Soc. London A325 105-126.

Fleitmann D, Burns S J, Mudelsee M, Neff U, Kramers J, Mangini A and Matter A 2003 Holocene forcing of the Indian monsoon recorded in a stalagmite from Southern Oman; Science 300 1737-1739.

Galy A and France-Lanord C 2001 Higher erosion rates in the Himalaya: Geochemical constraints on riverine fluxes; Geology 29 23-26.

Goodbred S L Jr and Kuehl S A 2000 Enormous GangesBrahmaputra sediment discharge during strengthened early Holocene monsoon; Geology 28 1083-1086.

Hedges J I and Keil R G 1995 Sedimentary organic matter preservation: An assessment and speculative synthesis; Mar. Chem. 49 81-115.

Hughen K A, Baillie M G L, Bard E, Bayliss A, Beck J W, Bertrand C, Blackwell P G, Buck C E, Burr G, Cutler K B, Damon P E, Edwards R L, Fairbanks R G, Friedrich M, Guilderson T P, Kromer B, McCormac F G, Manning S, Bronk Ramsey C, Reimer P J, Reimer R W, Remmele S, Southon J R, Stuiver M, Talamo S, Taylor F W, van der Plicht J and Weyhenmeyer C E 2004 Marine04 Marine radiocarbon age calibration, 0-26 cal kyr BP; Radiocarbon 46 1059-1086.

Jeandel C, Caisso M and Minster J F 1987 Vanadium behavior in the global ocean and in the Mediterranean Sea; Mar. Chem. 21 51-74.

King J, Banerjee S K, Marvin J and Ozdemir O 1982 A comparison of different magnetic methods for determining the relative grain size of magnetite in natural materials: Some results from lake sediments; Earth Planet. Sci. Lett. 59 404-419.

Klinkhammer G P and Palmer M R 1991 Uranium in the oceans: Where it goes and why; Geochim. Cosmochim. Acta 55 1799-1806.

Kolla V and Kidd R B 1982 Sedimentation and sedimentary processes in the Indian Ocean; In: The Ocean Basins and Margins (eds) Nairn A E M and Stehli F G (New York: Plenum) p. 1-50.

Langmuir D 1978 Uranium solution-mineral equilibria at low temperatures with application to sedimentary ore deposits; Geochim. Cosmochim. Acta 42 547-569.

Madhupratap M, Gauns M, Ramaiah N, Prasanna Kumar S, Muraleedharan P M, de Sousa S N, Sardessai S and Usha M 2003 Biogeochemistry of the Bay of Bengal: Physical, chemical and primary productivity characteristics of the central and western Bay of Bengal during summer monsoon 2001; Deep-Sea Res. II 50 881-896.

Milliman J D and Meade R H 1983 World-wide delivery of river sediment to the oceans; J. Geol. 9 1-19.

Mullins C E and Tite M S 1973 Magnetic viscosity, quadrature susceptibility and frequency dependence of susceptibility in single-domain assemblies of magnetite and maghemite; J. Geophys. Res. 78 804-809.

Murray R W, Brink M R B, Gerlach D C, Russ G P and Jones D L 1991 Rare earth, major and trace elements in chert from the Franciscan complex and Monterey Group, California: Assessing REE source to fine grained marine sediments; Geochim. Cosmochim. Acta 55 1875-1895.

Neff U, Burns S J, Mangini A, Mudelsee M, Fleitmann D and Matter A 2001 Strong coherence between solar variability and the monsoon in Oman between 9 and $6 \mathrm{kyr}$ ago; Nature 411 290-293.

Pattan J N and Higgs N C 1995 Rare earth element studies of surficial sediments from the southwestern Carlsberg Ridge, Indian Ocean; Proc. Indian Acad. Sci. (Earth Planet. Sci.) 104 569-578.

Piper D Z 1974 Rare earth elements in the sedimentary cycle; Chem. Geol. 17 287-297.

Prasad T G 1997 Annual and seasonal mean buoyancy fluxes for the tropical Indian Ocean; Curr. Sci. 73 667-674.

Prasanna Kumar S, Muraleedharan P M, Prasad T G, Gauns M, Ramaiah N, de Souza S N, Sardessai S and Madhupratap M 2002 Why is the Bay of Bengal less productive during summer monsoon compared to the Arabian Sea; Geophys. Res. Lett. 292235 doi:10.1029/2002GL016013.

Prasanna Kumar S, Nuncio M, Narvekar J, Kumar A, Sardesai S, de Souza S N, Gauns M, Ramaiah N and Madhupratap M 2004 Are eddies nature's trigger to enhance biological productivity in the Bay of Bengal; Geophys. Res. Lett. 31 L07309 doi:10.1029/2003GL019274.

Ramage C S 1971 Monsoon Meteorology. Academic Press, New York.

Ramesh R, Ramanathan A L, Ramesh S, Purvaja R and Subramanian S 2000 Distribution of rare earth elements and heavy metals in the surficial sediments of the Himalayan river system; Geochem. J. 34 295-319.

Rashid H, Flower B P, Poore R Z and Quinn T M 2007 A $25 \mathrm{ka}$ Indian Ocean monsoon variability record from the Andaman Sea; Quat. Sci. Rev. 26 2586-2597.

Ravi Prasad G V, Dutta K and Ray D K 2008 Radiocarbon AMS at IOP: System improvements and dating of groundwater from Bhadrak district, Orissa; Nucl. Instr. Meth. Phys. Res. (B) 266 1833-1836.

Sahota J T S, Robinson S G and Oldfield F 1995 Magnetic measurements used to identify paleoxidation fronts in deep-sea sediments from the Madeira Abyssal Plain; Geophys. Res. Lett. 22 1961-1964.

Schulz H, von Rad U and Erlenkeuser H 1998 Correlations between Arabian Sea and Greenland climate oscillations of the past 110,000 years; Nature 393 54-57.

Shankar D, Vinayachandran P N and Unnikrishnan A S 2002 The monsoon currents in the north Indian Ocean; Progr. Oceanogr. 52 62-120.

Shetye S R, Shenoi S S C, Gouveia A D, Michael G S, Sundar D and Nampoothiri G 1991 Wind-driven coastal upwelling along the western boundary of the Bay of Bengal during southwest monsoon; Cont. Shelf Res. 11 1397-1408.

Shetye S R, Gouveia A D, Shenoi S S C, Sundar D, Michael G S and Nampoothiri G 1993 The western boundary current of the seasonal subtropical gyre in the Bay of Bengal; J. Geophys. Res. 98(C1) 945-954.

Southon J, Kashgarian M, Fontugne M, Metivier B and Yim W W S 2002 Marine reservoir corrections for the Indian Ocean and Southeast Asia; Radiocarbon 44 $167-180$

Stow D A V, Amano K, Balson P S, Brass G W, Corrigan J, Raman C V, Tiercelin J J, Townsend M and 
Wijayananda N P 1990 Sediment Facies and processes on the distal Bengal Fan, Leg 116. In: Proceedings of the Ocean Drilling Program Scientific Results (eds) Cochran J R, Curray J R, Sager W W and Stow D A V, $116377-396$.

Subramanian V 1979 Chemical and suspended sediment characteristics of rivers of India; J. Hydrol. 44 37-55.

Subramanian V 1985 Geochemistry of river basins in the Indian subcontinent, Part I: Water chemistry, chemical erosion and water-mineral equilibria; In: Transport of carbon and minerals in major world rivers (eds) Degens E T and Kempe S (Hamburg: Mittilungen aus dem Geologisch-Palaeontologischen, Institut der Universitat Hamburg) 58 494-512.

Subramanian V 1993 Sediment load of Indian rivers; Curr. Sci. $64928-930$.

Subramanian V, Van’t Dack L and Van Grieken R 1985 Chemical composition of river sediments from the Indian subcontinent; Chem. Geol. 48 271-279.
Subramanian V, Van't Dack L and Van Grieken R 1987 Heavy metal distribution in the sediments of Ganges and Brahmaputra River; Environ. Geol. Water Sci. 9 93-103.

Taylor S R and McLennan S M 1985 The continental crust: Its composition and evolution (London: Blackwell) $300 \mathrm{p}$. Varkey M J, Murthy V S N and Suryanarayana A 1996 Physical oceanography of the Bay of Bengal and Andaman Sea; Oceanogr. Mar. Biol. 34 1-70.

Vogel J S, Southon J R, Nelson D E and Brown T A 1984 Performance of catalytically condensed carbon for use in accelerator mass spectrometry; Nucl. Instr. Meth. Phys. Res. (B) 5 289-293.

Wedepohl K H 1991 The composition of the upper earth's crust and the natural cycles of selected metals. Metals in natural raw materials. Natural Resources; In: Metals and their compounds in the Natural Environment (ed) Merian E (Weinheim, VCH-Verlagsges) p. $3-17$. 